
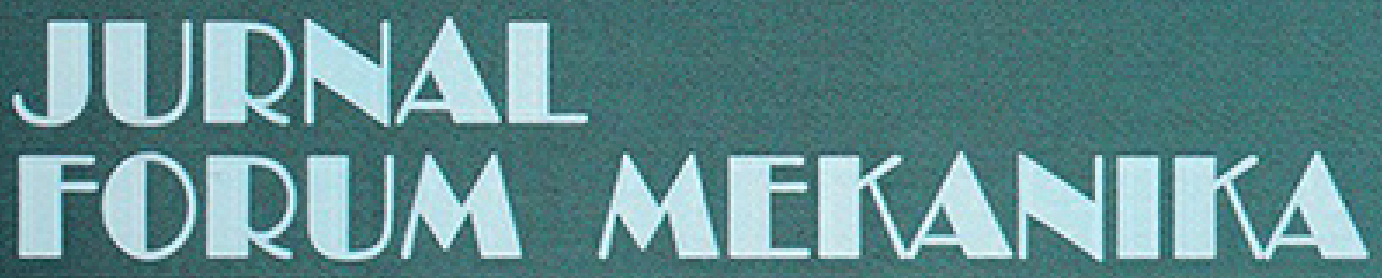

Volume 6 - Nomor 2 November 2017 ISSN : 2356-1491

ANALISIS RUMAH KABEL BAWAH TANAH PADA PROYEK PEKERJAAN JARINGAN UTILITAS SKTT 150 KV PLUMPANG - GAMBIR DYAH PRATIWI KUSUMASTUTI; IRMA SEPRIYANNA

STUDI KOMPARASI ANTARA PRACETAK MASIF DAN FLY SLAB STUDI KASUS: STRUKTUR GEDUNG RUSUNAWA SURAKARTA BUDI WICAKSONO

SISTEM DRAINASE ALIRAN BAWAH TANAH UNTUK DAERAH RAWAN LONGSOR (STUDI KASUS SUB DAS SUNGAI CIKAPUNDUNG, BANDUNG) ENDAH LESTARI

ANALISA STATISTIK DEBIT BANIIR DAN DEBIT ANDALAN SUNGAI KOMERING SUMATERA SELATAN DEVITA MAYASARI

STUDI EKSPERIMENTAL KUAT LENTUR BAJA PROFIL I KOMPAK SIMETRIS GANDA BERDASARKAN RSNI 03-1729-201X

DICKI DIAN PURNAMA; AKHMAD AMINULLAH; MUSLIKH

PENGGUNAAN PASIR LAUT TERHADAP KUAT TEKAN BETON KOTA BENGKULU TOMMYIDUWIN

ANALISA PENGARUH ADMIXTURE TERHADAP ABU TERBANG (FLY ASH) DAN BOTTOM ASH

TRI YUHANAH; NOVIA ADE MANDASARI

ANALISA KINERJA PERSIMPANGAN BERSINYAL PADA PERSIMPANGAN ANGKATAN 66 DAN RUAS JALAN R. SOEKAMTO KOTA PALEMBANG YULES PRAMONA ZULKARNAIN; IRMA INDRIANI 


\title{
STUDI KOMPARASI ANTARA PRACETAK MASIF DAN FLY SLAB STUDI KASUS: STRUKTUR GEDUNG RUSUNAWA SURAKARTA
}

\author{
BUDI WICAKSONO \\ Jurusan Teknik Sipil, Sekolah Tinggi Teknik PLN Jakarta \\ Email: budi.wicaksono.bon@gmail.com
}

\begin{abstract}
Abstrak
Fly slab merupakan salah satu pengembangan teknologi precast pada plat lantai beton yang telah diteliti dan dipatenkan oleh Ir. Sulistyana pada tahun 2011. Konsep yang digunakan adalah mengurangi massa plat lantai beton pracetak dengan membuat rib-rib pada plat lantai beton. Dengan meminimalisir volume beton pada daerah tarik plat lantai serta tetap menjaga mekanisme transfer gaya dari beton ke tulangan atau sebaliknya, diharapkan dapat mereduksi massa struktur tanpa mengurangi kekuatannya. Studi komparasi yang dilakukan dalam penelitian adalah studi komparasi berdasarkan perencanaan Pembangunan Gedung Rusunawa Surakarta, Jawa Tengah. Studi komparasi ini dilakukan dengan membandingkan hasil perencanaan struktur Rusunawa Surakarta yang sudah ada dan siap bangun menggunakan beton pracetak masif, dengan perencanaan struktur baru Rusunawa Surakarta menggunakan plat lantai fly slab serta elemen struktur balok dan kolom menggunakan beton konvensional. Berdasarkan hasil analisa, didapatkan hasil reduksi volume beton dan tulangan pada elemen struktur balok Gedung Rusunawa Surakarta sebesar 20,25\% dan 6,3\%. Reduksi reaksi vertikal struktur Gedung Rusunawa Surakarta sebesar 16,93\%.
\end{abstract}

Kata kunci : Fly Slab, Studi Komparasi, Reduksi volume beton, Reduksi Volume Tulangan, Reaksi Vertikal Struktur.

\begin{abstract}
Fly slab is one of the precast concrete slab technological development that has been researched and patented by Ir. Sulistyana in 2011. The concept is how to reduce the mass of precast concrete slab with makes ribs on the concrete slab. To minimize the volume of concrete plate and while maintaining tensile area to makes the style transfer mechanism of concrete to reinforcement or otherwise, are expected to reduce the mass of the structure without reducing strength. Comparative study will be conducted in this research based on Planning of Building Construction Rusunawa in Surakarta, Central Java. This comparative study is done by compare the results of the structural design Rusunawa existing Surakarta and ready to build using conventional precast concrete massive, with a new structure plan Rusunawa Surakarta with using fly slab as material plate, beam and column structural elements using conventional concrete. Based on the analysis results, showed reduction in the volume of concrete and reinforcement elements beam and coloumn Rusunawa Surakarta structure is 20,25\% and 6,3\%. Reduction reaction in the vertical structure of the Rusunawa Building in Surakarta is 16,93\%.
\end{abstract}

Keywords : Fly Slab, Comparative Study, Reduction of Concrete, Reduction of Reinforcement, Reaction of Vertical Structure.

\section{Latar Belakang}

Efektivitas pengelolaan proyek besar dapat diusahakan dengan menerapkan metode kerja yang tepat. Output yang diperoleh adalah reduksi biaya proyek dan waktu. Pada proyek yang mempunyai kegiatan pekerjaan beton dengan volume besar dan bentuk tipikal serta repetitif, umumnya metode cast in situ dan precast menjadi alternatif pilihan dalam pengambilan keputusan.

Metode precast memberikan banyak keuntungan dibandingkan metode cast in situ. Komponen precast dirancang untuk meminimalkan bekisting. Sebagai hasilnya diperoleh penghematan waktu dan biaya konstruksi. Penghematan secara keseluruhan pada bahan bangunan membawa dampak yang signifikan terhadap lingkungan.

Fly slab merupakan salah satu pengembangan teknologi precast pada plat lantai beton yang telah diteliti dan dipatenkan oleh Sulistyana, 2011 dalam tesisnya "Penelitian Panel Beton Seluler dengan Rib Sebagai Pengaku" [14] di Magister Teknik Sipil Universitas Diponegoro.

Berdasarkan penelitian tersebut, maka dalam penelitian ini akan dilakukan studi komparasi pada Proyek Gedung Rusunawa Surakarta. Proyek tersebut direncanakan menggunakan beton pracetak masif pada struktur balok, kolom dan plat lantai. Studi komparasi ini bertujuan untuk membandingkan besaran reduksi keterbutuhan material struktur yang 
terjadi pada struktur balok dan kolom akibat penggunaan plat lantai fly slab. Penggunaan fly slab ini juga diharapkan dapat menghasilkan reaksi vertikal struktur keseluruhan yang lebih kecil dari rencana awal. Semakin kecilnya beban vertikal yang terjadi pada struktur tentunya dapat dipastikan akan terjadi reduksi kebutuhan pondasi.

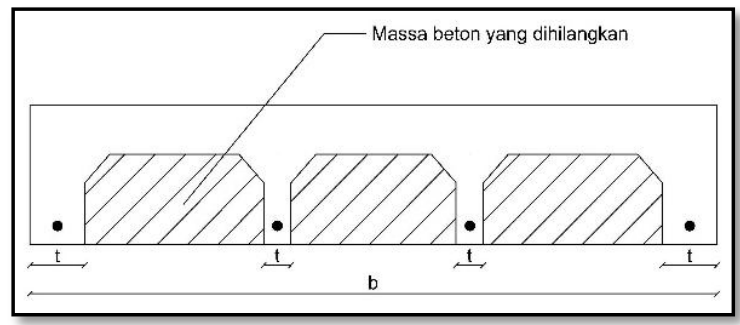

Gambar 1 Plat Lantai Beton Fly slab (Sumber : Sulistyana. 2011)

Tujuan dari studi komparasi ini adalah :

1. Mengevaluasi sistem struktur pracetak semi konvensional masif dengan sistem struktur plat lantai fly slab.

2. Menganalisis besaran reduksi volume beton dan volume tulangan struktur elemen balok dan kolom.

3. Menganalisis perbandingan reaksi vertikal struktur.

4. Mengevaluasi effisiensi penggunaan plat lantai fly slab. lain :

Adapun ruang lingkup studi komparasi ini antara

1. Struktur yang ditinjau adalah struktur portal 3D.

2. Mengasumsikan bahwa data - data gambar desain awal adalah valid dan dapat digunakan sebagai acuan.

3. Struktur Gedung Rusunawa Surakarta diasumsikan sebagai Struktur Rangka Pemikul Momen Khusus (SRPMK).

4. Studi komparasi ini hanya membandingkan besaran reaksi perletakan, tidak memperhitungkan kebutuhan pondasi.

5. Studi komparasi tidak meninjau perencanaan tangga, lift dan fasilitas penunjang bangunan lainnya.

6. Studi komparasi tidak meninjau metode pelaksanaan konstruksi, rencana anggaran biaya, manajemen konstruksi, dan spesifikasi teknis Struktur Gedung Rusunawa Surakarta.

\section{Landasan Teori}

Kriteria-kriteria yang harus digunakan adalah sebagai berikut :

1. Kemampuan Layanan (Serviceability)

2. Efisiensi

3. Konstruksi

4. Harga
Bagi kajian analisis, sistem struktur terdapat dua kategori dasar sistem, yaitu struktur kerangka (portal) dan struktur kontinum. Sistem struktur portal pada dasarnya di desain memiliki rangka ruang pemikul beban gravitasi secara lengkap yang disebut sebagai Sistem rangka pemikul momen ${ }^{[1]}$. Sistem rangka pemikul momen dibagi menjadi 3 jenis yaitu Sistem Rangka Pemikul Momen Khusus (SRPMK), Sistem Rangka Pemikul Momen Menengah (SRPMM), dan Sistem Rangka Pemikul Momen Biasa (SRPMB).

\section{Balok}

Pada struktur portal, balok berfungsi sebagai pemikul beban plat lantai yang menumpu di atasnya, kemudian dilimpahkan kepada kolom. Karena plat lantai fly slab yang memiliki berat lebih ringan dibandingkan dengan plat lantai konvensional / precast masif, maka beban yang dipikul balok akibat fly slab akan menjadi lebih ringan seperti pada ilustrasi Gambar 2.

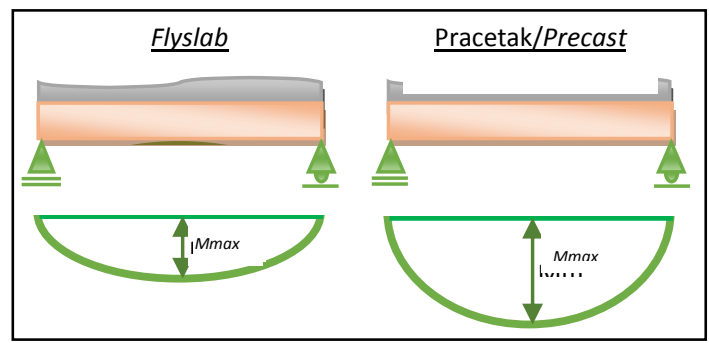

Gambar 2. Ilustrasi Bidang Momen Balok Akibat Beban Plat

(Sumber : Sulistyana. 2011)

\section{Perencanaan Balok}

Dalam menentukan komponen struktur lentur pada SRPMK maka harus memenuhi syarat di bawah ini $^{[6]}$ :

1. Gaya aksial tekan terfaktor pada komponen struktur tidak boleh melebihi $0,1 \times \mathrm{A}_{\mathrm{g}} \mathrm{x}^{\prime}{ }_{\mathrm{c}}$.

2. Bentang bersih komponen struktur tidak boleh kurang dari empat kali tinggi efektifnya.

3. Perbandingan lebar dan tinggi tidak boleh kurang dari 0,3 .

4. Lebarnya tidak boleh kurang dari $250 \mathrm{~mm}$

\section{Penulangan Lentur Balok}

Berikut adalah ketentuan-ketentuan dalam perencanaan penulangan balok pada Sistem Rangka Pemikul Momen Khusus (SRPMK) ${ }^{[6]}$, yaitu :

1. Pada setiap irisan penampang komponen struktur lentur, kecuali sebagaimana yang ditentukan SNI 03-2847-2002 Pasal 12.5.3 sebagai berikut :

a. Jumlah tulangan atas dan bawah tidak boleh kurang dari $\frac{b_{\mathrm{w}} \times d}{4 \times f_{\mathrm{y}}} \sqrt{\mathrm{f}^{\prime} \mathrm{c}}$, dan tidak boleh kurang dari $\frac{1.4 \times b_{w} \times d}{f y}$.

b. Rasio tulangan ( $\rho)$ tidak boleh melebihi 0,025 . 
c. Sekurang-kurangnya harus ada dua batang tulangan atas dan dua batang tulangan bawah yang dipasang secara menerus.

2. Kuat lentur positif komponen lentur pada muka kolom tidak boleh lebih kecil dari $1 / 2$ kuat lentur negatifnya pada muka kolom tersebut.

3. Sambungan lewatan pada tulangan lentur hanya diizinkan jika ada tulangan spiral atau sengkang tertutup yang mengikat bagian sambungan lewatan tersebut.

4. Baik kuat lentur negatif maupun kuat lentur positif pada setiap penampang di sepanjang bentang tidak boleh kurang dari $1 / 4$ kuat lentur terbesar yang disediakan pada kedua muka kolom tersebut.

\section{Kolom}

Kolom berfungsi memikul beban balok dan plat lantai yang kemudian akan dilimpahkan kepada pondasi. Karena plat lantai yang digunakan pada sistem struktur baru Gedung Rusunawa Surakarta adalah fly slab yang memiliki beban lebih ringan seperti Gambar 3.

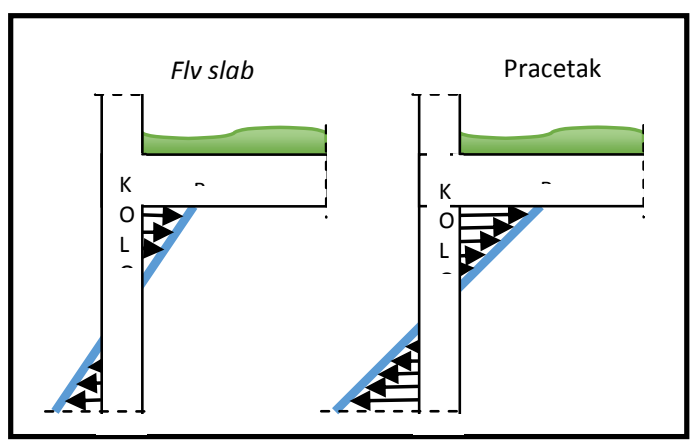

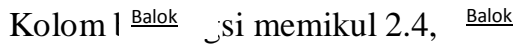

\section{Gambar 3. Bidang Momen Kolom Akibat Beban} Plat dan Balok

(Sumber : Sulistyana. 2011)

\section{Perencanaan Kolom}

Dalam menentukan komponen struktur yang menerima kombinasi lentur dan aksial pada SRPMK harus memenuhi kriteria sebagai berikut ${ }^{[6]}$ :

1. Gaya aksial tekan terfaktor lebih besar dari $0,1 \times A_{g} \times f^{\prime}{ }_{c}$.

2. Ukuran penampang terkecil, diukur pada garis lurus yang melalui titik pusat geometris > 300 $\mathrm{mm}$.

3. Perbandingan antara ukuran terkecil penampang terhadap ukuran dalam arah tegak lurusnya tidak kurang dari 0,4 .

\section{Penulangan Longitudinal Kolom}

Pengelupasan selimut beton sering terjadi di ujung-ujung kolom. Oleh karena itu, bila harus dipakai sambungan lewatan maka harus ditempatkan disekitar tengah ketinggian kolom dimana tegangan bolak-balik akan terjadi lebih kecil dibanding dengan yang terletak didekat hubungan balok-kolom. Berdasarkan Grafik dan Tabel Perhitungan Beton Bertulang, serta SNI 03 - 2847 - 2002 Pasal 23.4.2.2

Dalam perencanaan kolom digunakan prinsip Sistem Rangka Pemikul Momen Khusus (SRPMK) yaitu strong coloum weak beam dimana bertujuan untuk mengurangi kemungkinan leleh yang terjadi pada kolom. Jika kolom tidak lebih kuat dari kondisi balok-balok yang menyatu pada satu titik, ada kemungkinan terjadi aksi inelastik.

\section{Penulangan Transversal Kolom}

Tulangan transversal pada kolom merupakan fungsi dari kebutuhan desain gempa. Jika terjadi spalling pada selimut beton, maka kolom akan tetap mampu menopang beban aksial. Berikut ini adalah ketentuan-ketentuan dalam perencanaan tulangan transversal kolom ${ }^{[6]}$

\section{Fly Slab}

Fly slab merupakan optimasi elemen lentur plat beton panel seluler yang mereduksi massa plat beton tanpa mengurangi kapasitas lenturnya. Fly slab juga merupakan optimasi antara reduksi massa akibat pembentukan ruang dengan kemampuan panel seluler dalam menahan kuat lentur. Fly slab memiliki rib-rib yang berfungsi sebagai penahan gaya geser horizontal yang terjadi dan untuk menempatkan tulangan tarik. ${ }^{[14]}$

Awal mula fly slab ini muncul dari pengembangan model plat panel yang sudah pernah diteliti sebelumnya. Dari berbagai jenis model panel yang sudah ada, terdapat beberapa kekurangan yang membuat panel tersebut menjadi kurang optimal.

Maka fly slab menjadi solusi untuk mengatasi kekurangan-kekurangan pada plat panel sebelumnya. Secara sifat struktural plat lantai fly slab tidak berbeda dengan plat lantai pada umumnya, fly slab hanya mereduksi massa beton di daerah tarik saja.

Dengan demikian, upaya reduksi massa pada elemen lantai akan sangat berpengaruh secara signifikan terhadap pengurangan massa bangunan. Untuk kemudahan pelaksanaan di lapangan, fly slab dirancang sebagai plat pracetak yang diproduksi di pabrik. Hal tersebut akan berimbas kepada waktu pelaksanaan yang lebih cepat karena tidak perlu menunggu umur beton, sehingga pekerjaan selanjutnya bisa langsung dikerjakan.

Berdasarkan situs resmi fly slab (http://www.flyslab.co.id) menyatakan bahwa pada dasarnya beton fly slab itu dibuat tidak di tempat pelaksanaan proyek melainkan di tempat lain, misalnya pabrik. Sehingga akan menambah biaya angkut untuk transport beton pracetak ke lokasi proyek dan kelebihan juga, beton pracetak ini tidak terpengaruh cuaca yang berubah-ubah karena tidak dilakukan di lokasi proyek. 
Beberapa keuntungan dalam penggunaan beton pracetak fly slab pada struktur adalah sebagai berikut:

1) Kecepatan dalam pelaksanaan pembangunan.

2) Dicapainya tingkat flexibilitas dalam proses perancangannya.

3) Pekerjaan di lokasi proyek menjadi lebih sederhana.

4) Mempunyai aspek positif terhadap schedule, terutama kemudahan di dalam melakukan pengawasan dan pengendalian biaya serta jadwal pekerjaan.

5) Menggunakan tenaga buruh kasar sehingga upah relatif lebih murah.

6) Waktu konstruksi yang relatif lebih singkat karena pekerja lapangan (di lokasi proyek) hanya mengerjakan cast-in-situ dan kemudian menggabungkan dengan komponen-komponen beton pracetak.

7) Aspek kualitas, di mana beton dengan mutu prima dapat lebih mudah dihasilkan di lingkungan pabrik.

8) Produksinya tidak terpengaruh oleh cuaca.

9) Biaya yang dialokasikan untuk supervisi relatif lebih kecil. Hal ini disebabkan durasi proyek yang lebih singkat.

10) Kontinuitas proses konstruksi dapat terjaga sehingga perencanaan kegiatan dapat lebih akurat.

11) Mampu mereduksi biaya konstruksi.

12) Dapat dihasilkan struktur bangunan dengan akurasi dimensi dan mutu yang lebih baik.

Fly slab kini telah diproduksi secara massal dan dijual ke pasaran konstruksi. Fly slab dijual dalam beberapa tipe dan dapat menyesuaikan tipe berdasarkan kebutuhan lapangan sesuai ketentuan kapasitas ukuran fly slab. Beban per luasan fly slab adalah $120 \mathrm{~kg} / \mathrm{m}^{2}$.

\section{Metodologi Studi Komparasi}

Untuk acuan analisis perencanaan struktur baru Gedung Rusunawa Surakarta adalah sebagai berikut:

\section{1) Perhitungan Atap}

Atap direncanakan dengan bantuan software SAP 2000, dan analisis perhitungan sesuai dengan SNI 03-1729-2002 dan PPIUG 1983.

\section{2) Perhitungan Plat Lantai}

Plat lantai yang digunakan adalah plat lantai pracetak fly slab yang termasuk dalam kategori one way slab. Plat lantai fly slab dimana pada kondisi lapangan tipe plat lantai fly slab dapat menyesuaikan ukuran berdasarkan kebutuhan di lapangan selama memenuhi batasan-batasan ukuran fly slab.

\section{3) Perhitungan Portal (Balok dan Kolom)}

Balok dan kolom direncanakan dengan software SAP 2000, kemudian dianalisis sesuai dengan SNI
03-2847-2002. Khusus untuk kolom, dalam membuat diagram interaksi kolom digunakan software SP-Column.

\section{4) Perhitungan Gaya Gempa}

Analisis gempa struktur baru Gedung Rusunawa Surakarta dilakukan dengan menggunakan analisis gaya lateral ekivalen ${ }^{[7]}$

Proses studi komparasi struktur Gedung Rusunawa Surakarta dalam penelitian ini dimulai dari lingkup peninjauan Strukur Gedung Rusunawa Surakarta, kemudian dilanjutkan dengan mengumpulkan data-data yang diperlukan, mempelajari dan menentukan dasar - dasar teori yang akan dipakai dan terkait dengan studi komparasi ini, setelah itu mengidentifikasi bangunan yang direncanakan yang disertai dengan pengumpulan data yang dibutuhkan.

Langkah selanjutnya adalah penentuan dimensi struktur balok dan kolom. Kemudian dibuat pemodelan struktur baru Gedung Rusunawa Surakarta dengan menggunakan software SAP 2000 berdasarkan acuan data perencanaan awal yang sudah ada. Setelah pemodelan, dilakukan analisis dengan menggunakan software SAP 2000 untuk didapatkan gaya-gaya dalam yang bekerja. Setelah dianalisis kemudian dicek kembali, apakah struktur tersebut sudah memenuhi kriteria layak atau tidak.

Hasil output dari software SAP 2000 yaitu berupa gaya-gaya dalam yang terjadi dan kemudian digunakan dalam menganalisis kebutuhan tulangan elemen struktur balok dan kolom, serta menganalisis beban vertikal struktur yang terjadi pada struktur Gedung Baru Rusunawa Surakarta. Output hasil analisis dikomparasikan dengan data perencanaan awal yang sudah ada dengan menggunakan struktur beton precast masif.

Dari hasil komparasi tersebut akan didapatkan sebuah kesimpulan berapa persen volume tulangan dan volume beton pada elemen struktur balok dan kolom, serta besarnya perbandingan reaksi beban vertikal struktur yang mampu tereduksi akibat penggunaan elemen struktur plat lantai fly slab pada stuktur Gedung Rusunawa Surakarta.

\section{IV.Analisis dan Pembahasan}

Data pada rencana awal Gedung Rusunawa Surakarta seperti pada Gambar 1. didesain kembali dengan modul yang sama dan beberapa pendekatan perilaku, serta pada plat lantai direncanakan dengan plat lantai fly slab. Penentuan dimensi balok dan kolom dengan plat lantai fly slab diasumsikan sedemikian rupa dengan prinsip bahwa akibat penggunaan plat lantai fly slab membuat beban struktur menjadi lebih ringan.

Struktur plat lantai yang lebih ringan akan berdampak banyak pada reduksi perencanaan dan pelaksanaan struktur seperti pada kebutuhan struktur balok, kolom dan pondasi ${ }^{[14]}$. Hasil perencanaan 
struktur baru Gedung Rusunawa Surakarta akan dikomparasikan dengan data struktur awal Gedung Rusunawa Surakarta yang merupakan data aplikatif dan siap bangun untuk didapatkan hasil reduksinya.

Analisis struktur dilakukan dengan software SAP 2000 dengan konsep Open Frame Building yang meliputi pembebanan struktur gedung Rusunawa Surakarta, analisis gaya - gaya dalam yang terjadi, analisis kebutuhan dimensi dan tulangan balok dan kolom dan analisis beban vertikal struktur. Analisa pembebanan dilakukan berdasarkan acuan gambar kerja rencana awal Struktur Rusunawa Surakarta. Analisa pembebanan pada Struktur Baru Gedung Rusunawa Surakarta yang menggunakan plat lantai fly slab dilakukan dengan program SAP 2000.

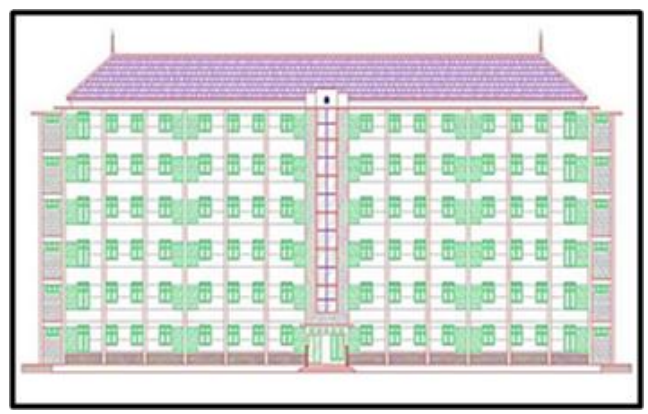

Gambar 4. Tampak Depan Gedung Rusunawa Surakarta (Sumber : hasil analisis)

Analisa struktur dilakukan dengan metode pradimensi di mana telah ditentukan terlebih dahulu dimensi dan tipe balok berdasarkan beban yang bekerja pada balok. Langkah awal dalam menganalisa pembebanan adalah pemodelan dengan software SAP 2000 seperti pada Gambar 5.

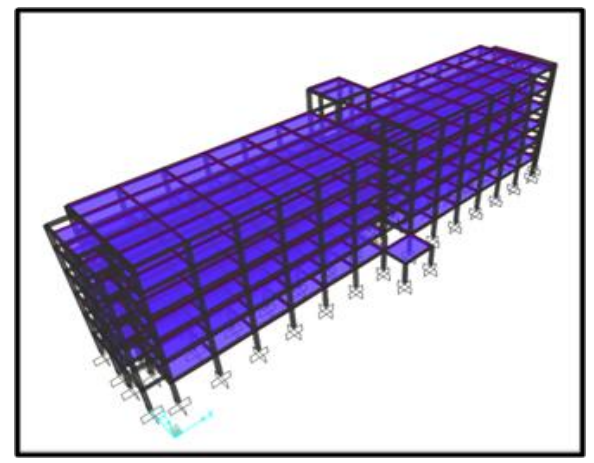

Gambar 5. Pemodelan Struktur Baru Gedung Rusunawa Surakarta

(Sumber : hasil analisis)

Hasil analisa SAP akan memberikan reaksi gaya dalam yang digunakan untuk merencanakan kebutuhan tulangan balok. Adapun beban-beban yang akan dianalisa dan bekerja pada struktur portal Gedung Rusunawa Surakarta adalah sebagai berikut:
1) Beban Mati (Dead Load).

Beban mati yang bekerja di dalam struktur Gedung Rusunawa Surakarta adalah beban sendiri struktur yang secara otomatis dihitung oleh software SAP 2000, tanpa perlu diinput besarnya beban. Yang termasuk beban mati adalah berat balok dan berat kolom.

2) Beban Mati Tambahan (Super Dead Load).

Beban Super Dead Load yang bekerja didalam struktur Gedung Rusunawa Surakarta adalah sebagai berikut :

\section{a. Beban Dinding.}

Besarnya beban dinding pasangan setengah batu bata merah adalah $250 \mathrm{~kg} / \mathrm{m}^{2}{ }^{[8]}$. Sehingga beban dinding yang bekerja adalah sebesar :

Dinding 3,25 meter $=250 \mathrm{~kg} / \mathrm{m}^{2} \times 3,25 \mathrm{~m}=$ $812,5 \mathrm{~kg} / \mathrm{m}^{2}$.

Dinding 2,75 meter $=250 \mathrm{~kg} / \mathrm{m}^{2} \times 2,75 \mathrm{~m}=$ $687,5 \mathrm{~kg} / \mathrm{m}^{2}$

b. Beban Spesi dan Penutup Lantai.

Besarnya beban adukan semen per $\mathrm{cm}$ tebal adalah sebesar $21 \mathrm{~kg} / \mathrm{m}^{2}{ }^{[8]}$, sedangkan beban penutup lantai tanpa adukan per $\mathrm{cm}$ tebal adalah sebesar $24 \mathrm{~kg} / \mathrm{m}^{2}$. Sehingga beban spesi dan penutup lantai yang bekerja adalah : Spesi dari semen tebal $3 \mathrm{~cm}$ $=3 \times 21 \mathrm{~kg} / \mathrm{m}^{2}=63 \mathrm{~kg} / \mathrm{m}^{2}$

Penutup lantai dari keramik $2 \mathrm{~cm}$

$=2 \times 24 \mathrm{~kg} / \mathrm{m}^{2}=48 \mathrm{~kg} / \mathrm{m}^{2}+63 \mathrm{~kg} / \mathrm{m}^{2}=111$ $\mathrm{kg} / \mathrm{m}^{2}$.

c. Beban Langit + Penggantung.

Besarnya beban langit-langit diambil sebesar 11 $\mathrm{kg} / \mathrm{m}^{2}$ dan besarnya beban penggantung sebesar 7 $\mathrm{kg} / \mathrm{m}^{2}{ }^{[8]}$. Sehingga beban total langit-langit dan penggantung yang bekerja adalah $11 \mathrm{~kg} / \mathrm{m}^{2}+7$ $\mathrm{kg} / \mathrm{m}^{2}=18 \mathrm{~kg} / \mathrm{m}^{2}$.

d. Beban Plat Fly Slab.

Besarnya beban fly slab yang bekerja pada struktur adalah sebesar $120 \mathrm{~kg} / \mathrm{m}^{2}{ }^{[14]}$. Karena plat fly slab merupakan tipe plat lantai one way slab, maka pembebanan fly slab dianalisis sebagai beban terbagi merata pada balok induk.

\section{3) Beban Hidup (Live Load).}

Berdasarkan PPIUG 1983, maka besarnya beban hidup yang bekerja pada struktur Gedung Rusunawa Surakarta adalah sebagai berikut ${ }^{[8]}$ :

a. Besarnya beban hidup untuk lantai adalah sebesar $250 \mathrm{~kg} / \mathrm{m}^{2}$.

b. Besarnya beban hidup untuk atap adalah sebesar $100 \mathrm{~kg} / \mathrm{m}^{2}$.

\section{4) Beban Gempa (Earthquake Load)}

Perhitungan gaya gempa yang terjadi pada struktur Gedung Rusunawa Surakarta dianalisa berdasarkan acuan SNI 03-1726-2012, dimana dalam melakukan analisis terhadap beban gempa digunakan metode gaya lateral ekivalen. Beban gempa Seperti 
Pada Tabel 4 dihitung berdasarkan berat total bangunan dan ketentuan SNI 03-1726-2012. Bebanbeban gempa pada Tabel 4.1 yang terjadi ditiap lantai tersebut, kemudian di distribusikan ke setiap joint dan di analisa menggunakan SAP 2000, selanjutnya hasil analisa digunakan untuk menghitung waktu getar dari struktur.

Tabel 1. Gaya Gempa Tiap Lanntai Pada Struktur Gedung Rusunawa Surakarta

\begin{tabular}{|c|c|c|c|c|c|}
\hline Lantai & $\begin{array}{c}\left(\mathbf{h}_{\mathbf{i}}\right) \\
(\mathbf{m})\end{array}$ & $\mathbf{W i}(\mathbf{k g})$ & $\begin{array}{c}\text { Wi.(}\left(\mathbf{h}_{\mathbf{i}}^{\mathbf{k}} \mathbf{)}\right. \\
(\mathbf{k g . m})\end{array}$ & $\mathbf{C}_{\mathrm{rx}}$ & $\begin{array}{c}\mathbf{F}_{\mathbf{x}}=\mathbf{F y} \\
(\mathbf{k g})\end{array}$ \\
\hline atap & 19.5 & 257409.341 & 6509339.787 & 0.133 & 35806.579 \\
\hline 5 & 16.25 & 703558.710 & 14591615.553 & 0.299 & 80265.564 \\
\hline 4 & 13.00 & 701578.710 & 11415364.863 & 0.234 & 62793.643 \\
\hline 3 & 9.75 & 701578.710 & 8348701.261 & 0.171 & 45924.539 \\
\hline 2 & 6.50 & 701578.710 & 5371798.046 & 0.110 & 29549.189 \\
\hline 1 & 3.25 & 705678.690 & 2542612.384 & 0.052 & 13986.403 \\
\hline Dasar & 0.00 & 776514.030 & 0.000 & 0.000 & 0.000 \\
\hline
\end{tabular}

(Sumber : hasil analisis)

\section{Pemeriksaan Waktu Getar}

Besarnya waktu getar yang terjadi pada arah sumbu X dan Y pada struktur dihitung berdasarkan persamaan berikut :

$$
\begin{aligned}
& \mathrm{T}_{\mathrm{RY}}=6,3 \times\left(\frac{3449.954}{980 \times 16 \times 16,310}\right)^{0,5} \\
& \mathrm{~T}_{\mathrm{RY}}=0,732 \text { detik } \\
& \mathrm{T}_{\mathrm{RX}}=6,3 \times\left(\frac{12288,022}{980 \times 4 \times 121,083}\right)^{0,5} \\
& \mathrm{~T}_{\mathrm{RX}}=1,014 \text { detik } \\
& \mathbf{T a} \text { maksimum }=\mathbf{0 , 9 4 5} \text { detik }
\end{aligned}
$$

Karena nilai $\mathrm{T}_{\mathrm{RY}}<\mathrm{Ta}$ maksimum, maka kekakuan struktur gedung ke arah Y memenuhi persyaratan. Perbedaan nilai $\mathrm{T}_{\mathrm{RX}}$ yang didapat dari rumus Rayleigh dengan nilai Ta maksimum $=6,897 \%$. Karena perbedaan selisih nilai $\mathrm{T}_{\mathrm{RX}}$ dengan nilai $\mathrm{Ta}$ maksimum diatas tidak melebihi $20 \% \mathrm{~m}$, maka kekakuan struktur gedung arah X memenuhi persyaratan waktu getar struktur. Hasil perhitungan waktu getar struktur

\begin{tabular}{|c|c|c|c|c|c|c|}
\hline Lantai & $\begin{array}{c}\mathrm{Wi} \\
\text { (Ton) } \\
\end{array}$ & $\begin{array}{c}\mathrm{di} \\
(\mathrm{cm}) \\
\end{array}$ & $\begin{array}{c}\mathrm{di}^{2} \\
\left(\mathrm{~cm}^{2}\right) \\
\end{array}$ & $\begin{array}{c}\text { Fix } \\
\text { (Ton) } \\
\end{array}$ & $\begin{array}{c}\text { Wi.di }^{2} \\
\left(\text { Ton.cm }^{2}\right) \\
\end{array}$ & $\begin{array}{c}\text { Fix.di } \\
\text { (Ton.cm) }\end{array}$ \\
\hline Atap & 256.873 & 0.6549 & 0.428 & 2.236 & 110.171 & 1.464 \\
\hline 6 & 702.504 & 0.9212 & 0.848 & 5.015 & 596.151 & 4.620 \\
\hline 5 & 700.524 & 1.197 & 1.432 & 3.924 & 1003.717 & 4.696 \\
\hline 4 & 700.524 & 1.197 & 1.432 & 2.870 & 1003.717 & 3.435 \\
\hline 3 & 700.524 & 0.9212 & 0.848 & 1.846 & 594.471 & 1.701 \\
\hline 2 & 709.306 & 0.447 & 0.199 & 0.880 & 141.726 & 0.393 \\
\hline 1 & 776.514 & 0 & 0 & 0.000 & 0.000 & 0.000 \\
\hline \multicolumn{5}{|c|}{ Jumlah } & 3449.954 & 16.310 \\
\hline
\end{tabular}
arah $\mathrm{Y}$ dan arah $\mathrm{X}$ dapat dilihat pada Tabel 2. dan Tabel 3

Tabel 2. Perhitungan Waktu Getar Alami

\begin{tabular}{|c|c|c|c|c|c|c|}
\hline Lantai & $\begin{array}{c}\begin{array}{c}\text { Wi } \\
\text { (Ton) }\end{array} \\
\end{array}$ & $\begin{array}{c}\mathrm{di} \\
(\mathrm{cm}) \\
\end{array}$ & $\begin{array}{c}\mathrm{di}^{2} \\
\left(\mathrm{~cm}^{2}\right) \\
\end{array}$ & $\begin{array}{c}\text { Fix } \\
\text { (Ton) } \\
\end{array}$ & $\begin{array}{c}\text { Wi.di }{ }^{2} \\
\left(\text { Ton.cm }^{2}\right)\end{array}$ & $\begin{array}{c}\begin{array}{c}\text { Fix.di } \\
\text { (Ton.cm) }\end{array} \\
\end{array}$ \\
\hline Atap & 256.873 & 0.923 & 0.851 & 8.944 & 218.838 & 8.255 \\
\hline 0 & 702.5 & 1.764 & 3.111 & 20.061 & 2185.979 & 35. \\
\hline 5 & 700.5 & 2.251 & 5.067 & 15.694 & 3549.555 & 35. \\
\hline 4 & 700.5 & 2.25 & 5.067 & 11.478 & 3549.555 & 7 \\
\hline 3 & 700.5 & 1.764 & 3.111 & 7.385 & 2179.817 & 13.028 \\
\hline 2 & 709.306 & 0.923 & 0.851 & 3.519 & 604.278 & 3.248 \\
\hline 1 & 776.5 & 0 & 0 & 0.000 & 0.000 & 0.000 \\
\hline \multicolumn{5}{|c|}{ Jumlah } & 12288.022 & 121.083 \\
\hline
\end{tabular}
Struktur Arah Y

(Sumber : hasil analisis)
Tabel 3. Perhitungan Waktu Getar Alami Struktur Arah X

(Sumber : hasil analisis)

Dari perencanaan keseluruhan terhadap

\begin{tabular}{|c|c|c|c|c|c|c|c|c|c|}
\hline \multirow{3}{*}{$\begin{array}{c}\text { Tipe } \\
\text { Balok }\end{array}$} & \multirow{3}{*}{$\begin{array}{c}\text { Dimensi } \\
\text { Penampang } \\
\left(\mathrm{mm}^{2}\right)\end{array}$} & \multicolumn{4}{|c|}{ Tulangan Tumpuan } & \multicolumn{4}{|c|}{ Tulangan Lapangan } \\
\hline & & \multicolumn{2}{|c|}{ Tulangan Atas } & \multicolumn{2}{|c|}{ Tulangan Bawah } & \multicolumn{2}{|c|}{ Tulangan Atas } & \multicolumn{2}{|c|}{ Tulangan Bawah } \\
\hline & & $\begin{array}{l}\text { Jumlah } \\
\text { (buah) }\end{array}$ & $\begin{array}{c}\mathrm{D} \\
(\mathrm{mm})\end{array}$ & $\begin{array}{l}\text { Jumlah } \\
\text { (buah) }\end{array}$ & $\begin{array}{c}\mathrm{D} \\
(\mathrm{mm})\end{array}$ & $\begin{array}{c}\text { Jumlah } \\
\text { (buah) }\end{array}$ & $\begin{array}{c}\mathrm{D} \\
(\mathrm{mm})\end{array}$ & \begin{tabular}{|l} 
Jumlah \\
(buah)
\end{tabular} & $\begin{array}{c}\text { D } \\
(\mathrm{mm})\end{array}$ \\
\hline Bl & $250 \times 350$ & 5 & 16 & 3 & 16 & 2 & 16 & 4 & 16 \\
\hline B2 & $250 \times 350$ & 6 & 16 & 3 & 16 & 2 & 16 & 5 & 16 \\
\hline B3 & $350 \times 450$ & 4 & 16 & 4 & 16 & 2 & 16 & 4 & 16 \\
\hline B3.1 & $250 \times 350$ & 2 & 16 & 2 & 16 & 2 & 16 & 2 & 16 \\
\hline B4 & $250 \times 350$ & 4 & 16 & 3 & 16 & 2 & 16 & 2 & 16 \\
\hline B5 & $250 \times 350$ & 3 & 16 & 2 & 16 & 2 & 16 & 2 & 16 \\
\hline B6 & $250 \times 350$ & 3 & 16 & 2 & 16 & 2 & 16 & 2 & 16 \\
\hline B7 & $250 \times 350$ & 2 & 16 & 2 & 16 & 2 & 16 & 2 & 16 \\
\hline B8 & $350 \times 450$ & 5 & 16 & 3 & 16 & 2 & 16 & 3 & 16 \\
\hline B9 & $250 \times 350$ & 5 & 16 & 3 & 16 & 2 & 16 & 2 & 16 \\
\hline $\mathrm{B} 10$ & $250 \times 350$ & 6 & 16 & 3 & 16 & 2 & 16 & 2 & 16 \\
\hline B11 & $250 \times 350$ & 3 & 16 & 3 & 16 & 2 & 16 & 2 & 16 \\
\hline $\mathrm{B} 12$ & $250 \times 350$ & 2 & 16 & 2 & 16 & 2 & 16 & 2 & 16 \\
\hline $\mathrm{B} 13$ & $250 \times 350$ & 4 & 16 & 2 & 16 & 2 & 16 & 2 & 16 \\
\hline BA & $200 \times 300$ & 2 & 16 & 3 & 16 & 2 & 16 & 3 & 16 \\
\hline
\end{tabular}
kebutuhan elemen struktur balok, didapatkan tipe dan jumlah tulangan pokok dan geser balok seperti pada Tabel 4 dan Tabel 5 .

Tabel 4. Tipe Balok Struktur Baru Gedung Rusunawa

(Sumber : hasil analisis)

Tabel 5. Tulangan Geser Balok

\begin{tabular}{|c|c|c|c|c|}
\hline Tipe & Tulangan Geser & $\begin{array}{c}\mathbf{D} \\
(\mathbf{m m})\end{array}$ & $\begin{array}{c}\text { So } \\
(\mathbf{m m})\end{array}$ & $\begin{array}{c}\text { Sx } \\
(\mathbf{m m})\end{array}$ \\
\hline B1 & $2-\mathrm{Leg}$ & 10 & 60 & 125 \\
\hline B2 & $2-\mathrm{Leg}$ & 10 & 60 & 125 \\
\hline B3 & $2-\mathrm{Leg}$ & 10 & 75 & 125 \\
\hline B3.1 & $2-\mathrm{Leg}$ & 10 & 75 & 125 \\
\hline B4 & 2-Leg & 10 & 70 & 125 \\
\hline B5 & 2-Leg & 10 & 70 & 125 \\
\hline B6 & 2-Leg & 10 & 70 & 125 \\
\hline B7 & 2-Leg & 10 & 70 & 125 \\
\hline B8 & 2-Leg & 10 & 60 & 125 \\
\hline B9 & 2-Leg & 10 & 60 & 125 \\
\hline B10 & 2-Leg & 10 & 60 & 125 \\
\hline B11 & 2-Leg & 10 & 70 & 125 \\
\hline B12 & 2-Leg & 10 & 70 & 125 \\
\hline B13 & 2-Leg & 10 & 70 & 125 \\
\hline BA & 2-Leg & 10 & 70 & 125 \\
\hline
\end{tabular}

(Sumber : hasil analisis)

Perencanaan tulangan kolom berprinsip bahwa kolom memiliki kemungkinan yang kecil untuk terjadi leleh dari pada balok sehingga ada batasan dalam perencanaan tulangan kolom agar lebih kuat dari balok seperti pada ilustrasi Gambar 6 . 


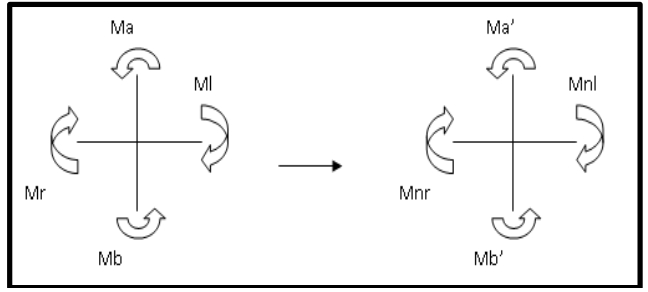

Gambar 6. Peningkatan Besar Momen akibat Pengaruh SRPMK

(Sumber : SNI 03-2847-2002)

Pada perencanaan tulangan kolom diambil kolom yang memiliki gaya aksial dan momen terbesar berdasarkan analisa SAP 2000. Dari perencanaan keseluruhan terhadap kebutuhan elemen struktur kolom dengan prosedur yang sama seperti di atas, didapatkan tipe dan jumlah tulangan pokok dan geser kolom seperti pada Tabel 6 dan Tabel 7 berikut ini.

Tabel.6. Tipe Kolom Struktur

\begin{tabular}{|c|c|c|c|}
\hline \multirow{2}{*}{ Type Kolom } & \multirow{2}{*}{$\begin{array}{c}\text { Dimensi } \\
\text { Kolom }\left(\mathbf{m m}^{2}\right)\end{array}$} & $\begin{array}{c}\text { Jumlah } \\
\text { (buah) }\end{array}$ & $\begin{array}{c}\text { Diameter } \\
\text { mm) }\end{array}$ \\
\hline \hline K1 & $350 \times 450$ & 8 & 16 \\
\hline K1.a & $350 \times 350$ & 8 & 16 \\
\hline
\end{tabular}

(Sumber : hasil analisis)

Tabel 7. Tulangan Geser Kolom

\begin{tabular}{|c|c|c|c|c|c|}
\hline \multirow{2}{*}{$\begin{array}{c}\text { Tipe } \\
\text { Kolom }\end{array}$} & \multirow{2}{*}{ D (mm) } & \multicolumn{2}{|c|}{ Lo (mm) } & \multicolumn{2}{c|}{ Ln (mm) } \\
\cline { 3 - 6 } & & $\begin{array}{c}\text { Tul. } \\
\text { Geser }\end{array}$ & $\begin{array}{c}\text { So } \\
(\mathbf{m m})\end{array}$ & $\begin{array}{c}\text { Tul. } \\
\text { Geser }\end{array}$ & $\begin{array}{c}\text { Sn } \\
(\mathbf{m m})\end{array}$ \\
\hline K1 & 10 & $4-$ leg & 50 & $2-$ leg & 150 \\
\hline K1.a & 10 & $2-$ leg & 80 & $2-$ leg & 150 \\
\hline
\end{tabular}

(Sumber : hasil analisis)

Analisis perbandingan rekasi vertikal dilakukan dengan bantuan program SAP 2000. Analisis ini dilakukan dengan membandingkan hasil reaksi perletakan antara kedua model struktur. Kedua model tipikal diberi perilaku sama dalam pembebanan dan modul. Perbedaannya hanya pada material plat lantai cuntuk stuktur awal menggunakan plat lantai pracetak masif seperti pada ilustrasi pemodelan Gambar 7 dan untuk struktur baru menggunakan fly slab dan memerlukan balok anak seperti pada ilustrasi pemodelan Gambar 8 karena keterbatasan ukuran minimum bentang panjang fly slab tidak lebih dari 4 meter. Dari analisis ini akan membuktikan dengan perbedaan beban plat lantai pada struktur akan menjadikan struktur lebih ringan dan tentunya akan berpengaruh pada kebutuhan pondasi.

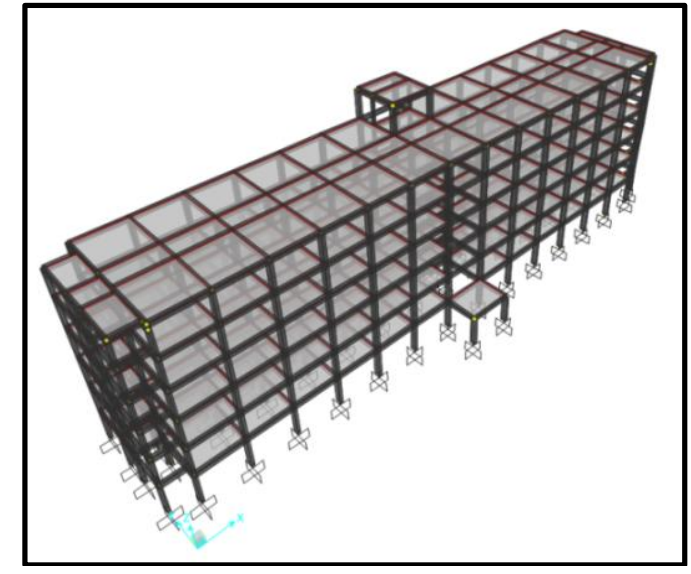

Gambar 7. Pemodelan Struktur Awal Rusunawa Surakarta (Sumber : hasil analisis)

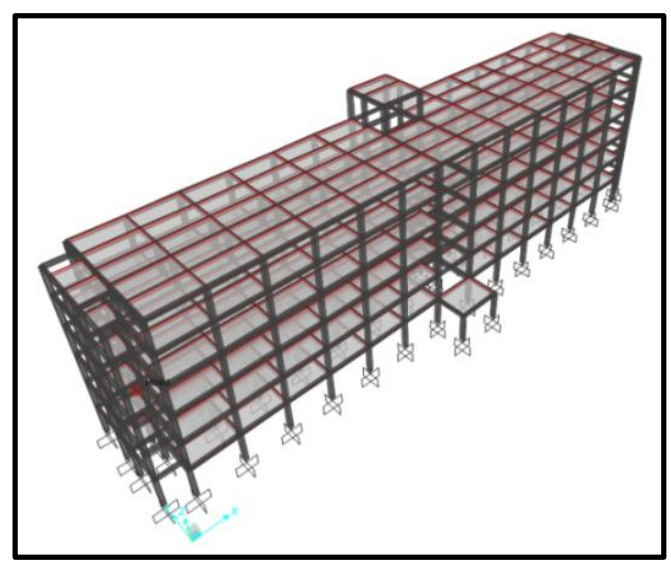

Gambar 8. Pemodelan Struktur Baru Rusunawa Surakarta (Sumber : hasil analisis)

Dari hasil analisis perhitungan yang telah dilakukan, maka dapat dilakukan analisa terhadap perbandingan besaran reduksi yang terjadi antara kebutuhan volume tulangan balok dan kolom, volume beton balok dan kolom serta perbandingan reaksi vertikal Struktur Gedung Rusunawa. Analisa reduksi dilakukan dengan menghitung keseluruhan terhadap total kebutuhan beton, tulangan dan reaksi vertikal yang terjadi. Berikut ini adalah data struktur rencana awal Gedung Rusunawa Surakarta yaitu: Tipe Kolom, Tulangan Geser Kolom, Tipe Balok dan Tulangan Geser Balok pada Tabel 8 - Tabel 11.

Tabel 8. Tipe Kolom Struktur Awal

\begin{tabular}{|c|c|c|c|}
\hline \multirow{2}{*}{$\begin{array}{c}\text { Tipe } \\
\text { Kolom }\end{array}$} & \multirow{2}{*}{$\begin{array}{c}\text { Dimensi } \\
\text { Penampang } \\
\left(\mathbf{m m}^{2}\right)\end{array}$} & $\begin{array}{c}|c| \\
\text { Tulangan } \\
\text { (buah) }\end{array}$ & $\begin{array}{c}\text { Jumlah } \\
\text { mm) }\end{array}$ \\
\hline \hline K1 & $300 \times 600$ & 10 & 16 \\
\hline K1.a & $300 \times 300$ & 6 & 16 \\
\hline K2 & $300 \times 600$ & 10 & 16 \\
\hline K2.a & $300 \times 300$ & 6 & 16 \\
\hline K3 & $300 \times 600$ & 8 & 16 \\
\hline
\end{tabular}

(Sumber : hasil analisis) 
Tabel 9. Tulangan Geser Kolom Struktur Awal

\begin{tabular}{|c|c|c|c|c|c|}
\hline \multirow{2}{*}{$\begin{array}{c}\text { Tipe } \\
\text { Kolom }\end{array}$} & \multirow{2}{*}{ D (mm) } & \multicolumn{2}{|c|}{ Lo (mm) } & \multicolumn{2}{c|}{ Ln (mm) } \\
\cline { 3 - 6 } & & $\begin{array}{c}\text { Tul. } \\
\text { Geser }\end{array}$ & $\begin{array}{c}\text { S0 } \\
(\mathbf{m m})\end{array}$ & $\begin{array}{c}\text { Tul. } \\
\text { Geser }\end{array}$ & $\begin{array}{c}\text { Sn } \\
(\mathbf{m m})\end{array}$ \\
\hline K1 & 10 & $2-$ leg & 100 & $2-$ leg & 150 \\
\hline K1.a & 10 & $2-$ leg & 100 & $2-$ leg & 150 \\
\hline K2 & 10 & $2-$ leg & 100 & $2-$ leg & 150 \\
\hline K2.a & 10 & $2-$ leg & 100 & $2-$ leg & 150 \\
\hline K3 & 10 & 2-leg & 100 & 2-leg & 150 \\
\hline
\end{tabular}

(Sumber : hasil analisis)

Tabel 10. Tipe Balok Struktur Awal

\begin{tabular}{|c|c|c|c|c|c|c|c|c|c|}
\hline \multirow{3}{*}{$\begin{array}{l}\text { Tipe } \\
\text { Balok }\end{array}$} & \multirow{3}{*}{$\begin{array}{c}\text { Dimensi } \\
\text { Balok } \\
(\mathrm{mm})\end{array}$} & \multicolumn{4}{|c|}{ Tulangan Tumpuan } & \multicolumn{4}{|c|}{ Tulangan Lapangan } \\
\hline & & \multicolumn{2}{|c|}{ Tulangan Atas } & \multicolumn{2}{|c|}{ Tulangan Bawah } & \multicolumn{2}{|c|}{ Tulangan Atas } & \multicolumn{2}{|c|}{ Tulangan Bawah } \\
\hline & & $\begin{array}{c}\text { Jumlah } \\
\text { (buah) }\end{array}$ & $\begin{array}{c}\mathrm{D} \\
(\mathrm{mm})\end{array}$ & $\begin{array}{l}\text { Jumlah } \\
\text { (buah) }\end{array}$ & $\begin{array}{c}\mathrm{D} \\
(\mathrm{mm}) \\
\end{array}$ & $\begin{array}{c}\text { Jumlah } \\
\text { (buah) }\end{array}$ & $\begin{array}{c}\mathrm{D} \\
(\mathrm{mm})\end{array}$ & $\begin{array}{l}\text { Jumlah } \\
\text { (bual) }\end{array}$ & $\begin{array}{c}\mathrm{D} \\
(\mathrm{mm}) \\
\end{array}$ \\
\hline $\mathrm{B} 1$ & $300 \times 500$ & 6 & 16 & 5 & 16 & 5 & 16 & 4 & 16 \\
\hline B1.1 & $300 \times 500$ & 6 & 16 & 5 & 16 & 5 & 16 & 4 & 16 \\
\hline B1.2 & $300 \times 500$ & 6 & 16 & 5 & 16 & 5 & 16 & 4 & 16 \\
\hline $\mathrm{B} 2$ & $300 \times 500$ & 6 & 16 & 5 & 16 & 5 & 16 & 4 & 16 \\
\hline B2.1 & $300 \times 500$ & 6 & 16 & 5 & 16 & 5 & 16 & 4 & 16 \\
\hline B3 & $300 \times 500$ & 6 & 16 & 5 & 16 & 5 & 16 & 4 & 16 \\
\hline B 3.1 & $300 \times 500$ & 6 & 16 & 5 & 16 & 5 & 16 & 4 & 16 \\
\hline $\mathrm{B} 4$ & $300 \times 500$ & 6 & 16 & 5 & 16 & 5 & 16 & 4 & 16 \\
\hline B4.1 & $300 \times 500$ & 6 & 16 & 5 & 16 & 5 & 16 & 4 & 16 \\
\hline B4.2 & $300 \times 500$ & 6 & 16 & 5 & 16 & 5 & 16 & 4 & 16 \\
\hline B4.3 & $300 \times 500$ & 6 & 16 & 5 & 16 & 5 & 16 & 4 & 16 \\
\hline B5 & $300 \times 500$ & 6 & 16 & 5 & 16 & 5 & 16 & 4 & 16 \\
\hline B6 & $300 \times 500$ & 6 & 16 & 5 & 16 & 5 & 16 & 4 & 16 \\
\hline B7 & $300 \times 500$ & 6 & 16 & 5 & 16 & 5 & 16 & 4 & 16 \\
\hline
\end{tabular}

(Sumber : hasil analisis)

Tabel 11. Tulangan Geser Balok Struktur Awal

\begin{tabular}{|c|c|c|c|c|}
\hline $\begin{array}{c}\text { Tipe } \\
\text { Balok }\end{array}$ & $\begin{array}{c}\text { Tul. } \\
\text { Geser }\end{array}$ & $\begin{array}{c}\text { D } \\
(\mathbf{m m})\end{array}$ & $\begin{array}{c}\text { So } \\
(\mathbf{m m})\end{array}$ & $\begin{array}{c}\text { Sx } \\
(\mathbf{m m})\end{array}$ \\
\cline { 2 - 5 } B1 & 2-Leg & 10 & 125 & 150 \\
\hline B1.1 & 2-Leg & 10 & 125 & 150 \\
\hline B1.2 & 2-Leg & 10 & 125 & 150 \\
\hline B2 & 2-Leg & 10 & 125 & 150 \\
\hline B2.1 & 2-Leg & 10 & 125 & 150 \\
\hline B3 & 2-Leg & 10 & 125 & 150 \\
\hline B3.1 & 2-Leg & 10 & 125 & 150 \\
\hline B4 & 2-Leg & 10 & 125 & 150 \\
\hline B4.1 & 2-Leg & 10 & 125 & 150 \\
\hline B4.2 & 2-Leg & 10 & 125 & 150 \\
\hline B4.3 & 2-Leg & 10 & 125 & 150 \\
\hline B5 & 2-Leg & 10 & 125 & 150 \\
\hline B6 & 2-Leg & 10 & 125 & 150 \\
\hline B7 & 2-Leg & 10 & 125 & 150 \\
\hline
\end{tabular}

(Sumber : hasil analisis)

Berikut adalah hasil analisa reduksi yang terjadi pada struktur. Rusunawa Surakarta pada Tabel $12-$ Tabel 16.

Tabel 12. Reduksi Volume Beton Kolom

\begin{tabular}{|c|c|c|c|}
\hline Struktur & $\begin{array}{c}\text { Volume } \\
\text { Beton } \\
\left(\mathbf{m}^{\mathbf{s}}\right)\end{array}$ & $\begin{array}{c}\text { Selisih Volume } \\
\text { Beton } \\
\left(\mathbf{m}^{\mathbf{3}}\right)\end{array}$ & $\begin{array}{c}\text { Reduksi Volume } \\
\text { Beton } \\
(\%)\end{array}$ \\
\hline \hline Struktur Pracetak & 230,355 & \multirow{2}{*}{26,419} & 11,469 \\
\hline Struktur Fly Slab & 203,936 & & \multirow{2}{*}{. } \\
\hline
\end{tabular}

(Sumber : hasil analisis)
Tabel 13. Reduksi Volume Tulangan Geser Kolom

\begin{tabular}{|c|c|c|c|}
\hline Struktur & $\begin{array}{c}\text { Berat } \\
\text { Tulangan } \\
(\mathrm{kg})\end{array}$ & $\begin{array}{c}\text { Selisih Berat } \\
\text { Tulangan } \\
(\mathrm{kg})\end{array}$ & $\begin{array}{c}\text { Reduksi Berat } \\
\text { Tulangan } \\
(\%)\end{array}$ \\
\hline \hline Struktur Pracetak & 13908,816 & \multirow{2}{*}{$-454,704$} & $-3,26$ \\
\hline Struktur Fly Slab & 14363,520 & & \\
\hline
\end{tabular}

(Sumber : hasil analisis)

Tabel 14. Reduksi Volume Tulangan Longitudinal Kolom

\begin{tabular}{|c|c|c|c|}
\hline Struktur & $\begin{array}{c}\text { Berat } \\
\text { Tulangan } \\
(\mathbf{k g})\end{array}$ & $\begin{array}{c}\text { Selisih Berat } \\
\text { Tulangan } \\
(\mathbf{k g})\end{array}$ & $\begin{array}{c}\text { Reduksi Berat } \\
\text { Tulangan } \\
(\%)\end{array}$ \\
\hline \hline Struktur Pracetak & 20337,012 & \multirow{2}{*}{2510,661} & 12,345 \\
\cline { 1 - 2 } Struktur Fly Slab & 17826,350 & & \\
\hline
\end{tabular}

(Sumber : hasil analisis)

Tabel 15. Reduksi Volume Beton Balok

\begin{tabular}{|c|c|c|c|}
\hline Struktur & $\begin{array}{c}\text { Volume } \\
\text { Beton } \\
\left(\mathbf{m}^{\mathbf{3}}\right)\end{array}$ & $\begin{array}{c}\text { Selisih } \\
\text { Volume Beton } \\
\left(\mathbf{m}^{\mathbf{3}}\right)\end{array}$ & $\begin{array}{c}\text { Reduksi } \\
\text { Volume Beton } \\
(\%)\end{array}$ \\
\hline \hline Struktur Pracetak & 387,810 & \multirow{2}{*}{98,306} & 25,349 \\
\hline Struktur Fly Slab & 289,504 & & \\
\hline
\end{tabular}

(Sumber : hasil analisis)

Tabel 16. Reduksi Volume Tulangan Geser Balok

\begin{tabular}{|c|c|c|c|}
\hline Struktur & $\begin{array}{c}\text { Berat } \\
\text { Tulangan } \\
(\mathrm{kg})\end{array}$ & $\begin{array}{c}\text { Selisih Berat } \\
\text { Tulangan } \\
(\mathrm{kg})\end{array}$ & $\begin{array}{c}\text { Reduksi Berat } \\
\text { Tulangan } \\
(\%)\end{array}$ \\
\hline Struktur Pracetak & 16191,36 & \multirow{2}{*}{4702,2} & $-29,04$ \\
\hline Struktur Fly Slab & 20893,56 & & \\
\hline
\end{tabular}

(Sumber : hasil analisis)

Tabel 17. Reduksi Volume Tulangan Pokok Balok

\begin{tabular}{|c|c|c|c|}
\hline Struktur & $\begin{array}{c}\text { Berat } \\
\text { Tulangan } \\
(\mathrm{kg})\end{array}$ & $\begin{array}{c}\text { Selisih Berat } \\
\text { Tulangan } \\
(\mathrm{kg})\end{array}$ & $\begin{array}{c}\text { Reduksi Berat } \\
\text { Tulangan } \\
(\%)\end{array}$ \\
\hline \hline Struktur Pracetak & 48021,26 & \multirow{2}{*}{8856,84} & 18,44 \\
\hline Struktur Fly Slab & 39164,42 & & \multirow{2}{|l|}{80,44} \\
\hline
\end{tabular}

(Sumber : hasil analisis)

Tabel 18. Reduksi Reaksi Vertikal

\begin{tabular}{|c|c|c|c|}
\hline Struktur & $\begin{array}{c}\text { Reaksi } \\
\text { Vertikal } \\
(\mathbf{K g})\end{array}$ & $\begin{array}{c}\text { Selisih Reaksi } \\
\text { Vertikal } \\
(\mathbf{k g})\end{array}$ & $\begin{array}{c}\text { Reduksi Reaksi } \\
\text { Vertikal } \\
(\%)\end{array}$ \\
\hline \hline Struktur Pracetak & 7506156 & \multirow{2}{*}{1270917} & 16,93 \\
\hline Struktur Fly Slab & 6235239 & & \multirow{2}{*}{. } \\
\cline { 1 - 2 }
\end{tabular}

(Sumber : hasil analisis)

Terlihat bahwa tidak terjadi reduksi pada kebutuhan geser, hal ini disebabkan karena pada data rencana awal struktur Gedung Rusunawa Surakarta tidak memenuhi kriteria SNI 03-2847-2002. Hal ini terbukti dengan analisa berikut :

\section{$\underline{\text { Balok }}$}

Hoops pertama dipasang pada jarak $50 \mathrm{~mm}$ dari muka kolom terdekat dan yang berikutnya dipasang dengan spasi terkecil diantara ${ }^{[6]}$ :

1. $\mathrm{d} / 4=(500-40) / 4=115 \mathrm{~mm}$.

2. $8 \mathrm{x} \mathrm{db}$ longitudinal terkecil

$=8 \times 16 \mathrm{~mm}=128 \mathrm{~mm}$. 
3. 24 kali diameter tulangan hoops $=24 \times 10 \mathrm{~mm}=240 \mathrm{~mm}$.

4. $300 \mathrm{~mm}$.

Jadi seharusnya pada tulangan geser rencana awal menggunakan jarak $<115 \mathrm{~mm}$ pada So.

\section{Kolom}

Tulangan transversal harus diletakkan dengan spasi tidak lebih daripada ${ }^{[6]}$ :

1. $\frac{1}{4}$ dimensi terkecil komponen Struktur.

$$
=\frac{1}{4} \times 300 \mathrm{~mm}=75 \mathrm{~mm}
$$

2. $6 x$ diameter tulangan longitudinal

$$
=6 \times 16 \mathrm{~mm}=96 \mathrm{~mm}
$$

3. $\mathrm{s}_{\mathrm{x}}$ sesuai persamaan dibawah ini :

$$
\begin{aligned}
& \mathrm{s}_{\mathrm{x}}=100+\frac{350-\mathrm{h}_{\mathrm{x}}}{3}, \\
& \text { dimana nilai } \\
& \mathrm{h}_{\mathrm{x}}=\frac{2}{3} \times \mathrm{h}_{\mathrm{c}}=\frac{2}{3} \times 210 \mathrm{~mm} \\
& \mathrm{~h}_{\mathrm{x}}=140 \mathrm{~mm} \\
& \text { Jadi nilai } \mathrm{s}_{\mathrm{x}} \text { sebesar }: \\
& \mathrm{s}_{\mathrm{x}}=100+\frac{350-140}{3} \\
& \mathrm{~s}_{\mathrm{x}}=170 \mathrm{~mm}
\end{aligned}
$$

Untuk nilai $\mathrm{s}_{\mathrm{x}}$ tidak perlu lebih besar daripada $150 \mathrm{~mm}$ dan tidak perlu lebih kecil dari $100 \mathrm{~mm}$.

Jadi seharusnya pada rencana awal tulangan geser pada kolom menggunakan jarak $<75 \mathrm{~mm}$ pada Lo. Karena adanya ketidaksesuaian terhadap acuan yang berlaku pada perencanaan tulangan geser balok dan kolom, maka tulangan geser balok dan kolom tidak layak untuk dibandingkan sebagai hasil reduksi. Namun karena hal ini patut dijadikan sebagai bahan analisa atau kajian untuk selanjutnya maka tetap diperhitungkan total keseluruhan reduksi yang terjadi pada kebutuhan volume tulangan dan beton pada balok dan kolom seperti pada Tabel 19 dan Tabel 20.

Tabel 19. Reduksi Volume Tulangan Total

\begin{tabular}{|c|c|c|c|}
\hline Struktur & $\begin{array}{c}\text { Berat } \\
\text { Tulangan } \\
(\mathbf{k g})\end{array}$ & $\begin{array}{c}\text { Selisih Berat } \\
\text { Tulangan } \\
(\mathbf{k g})\end{array}$ & $\begin{array}{c}\text { Reduksi Berat } \\
\text { Tulangan } \\
(\%)\end{array}$ \\
\hline \hline Struktur Pracetak & 98458,448 & \multirow{2}{*}{6210,598} & 6,308 \\
\hline Struktur Fly Slab & 92247,850 & & \\
\hline
\end{tabular}

(Sumber : hasil analisis)

Tabel 20. Reduksi Volume Beton Total

\begin{tabular}{|c|c|c|c|}
\hline Struktur & $\begin{array}{c}\text { Berat } \\
\text { Tulangan } \\
(\mathbf{k g})\end{array}$ & $\begin{array}{c}\text { Selisih Berat } \\
\text { Tulangan } \\
(\mathbf{k g})\end{array}$ & $\begin{array}{c}\text { Reduksi Berat } \\
\text { Tulangan } \\
(\%)\end{array}$ \\
\hline \hline Struktur Pracetak & 618,165 & \multirow{2}{*}{124,725} & $20,25 \%$ \\
\hline Struktur Fly Slab & 493,44 & & \\
\hline
\end{tabular}

(Sumber : hasil analisis)

\section{Kesimpulan}

1. Reduksi volume beton pada elemen struktur balok Gedung Rusunawa Surakarta sebesar $25,349 \%$.

2. Reduksi volume tulangan pada elemen struktur balok Gedung Rusunawa Surakarta sebesar 18,44 $\%$.

3. Reduksi volume tulangan geser pada elemen struktur balok Gedung Rusunawa Surakarta sebesar $-29,04 \%$.

4. Reduksi volume beton pada elemen struktur kolom Gedung Rusunawa Surakarta sebesar $11,469 \%$.

5. Reduksi volume tulangan pada elemen struktur kolom Gedung Rusunawa Surakarta sebesar $12,345 \%$.

6. Reduksi volume tulangan geser pada elemen struktur kolom Gedung Rusunawa Surakarta sebesar $-3,26 \%$.

7. Reduksi reaksi vertikal pada struktur Gedung Rusunawa Surakarta sebesar 16,93\%.

Hasil reduksi total tulangan adalah $6,3 \%$ dan reduksi total beton adalah $20,25 \%$. Sehingga dapat disimpulkan bahwa penggunaan plat lantai fly slab dengan struktur kolom dan balok konvensional cukup efektif dibandingkan penggunaan plat lantai precast konvensional masif. Hal ini terbukti dengan telah tereduksinya volume beton dan tulangan pada elemen struktur balok dan kolom. Meskipun tulangan geser tidak tereduksi karena secara analisa pada perencanaan awal tidak memenuhi ketentuan SNI 03-2847-2002, tetapi secara keseluruhan struktur tetap memberikan reduksi meskipun kecil dan secara bagian struktur untuk tulangan longitudinal dan beton pada balok dan kolom cukup memberikan hasil reduksi yang besar.

Jadi dengan menggunakan elemen fly slab dapat meningkatkan effisiensi penggunaan material struktur yang tentunya akan banyak memberikan keuntungan. Dari hasil reaksi vertikal struktur juga tereduksi hingga $16,93 \%$, hal ini membuktikan bahwa berat gedung semakin ringan tentunya akan berdampak pada kebutuhan pondasi yang akan tereduksi juga namun hal ini hanya terjadi pada kondisi tanah yang sama seperti pada lokasi Gedung Rusunawa Surakarta.

\section{DAFTAR PUSTAKA}

[1] Asroni A. (1), 2010. Balok dan Pelat Beton Bertulang, Graha Ilmu : Yogyakarta.

[2] Asroni A. (2), 2010. Kolom Fondasi dan Balok T Beton Bertulang, Graha Ilmu : Yogyakarta.

[3] Badan Standarisasi Nasional,Tata Cara Perencanaan Ketahanan Gempa Untuk Struktur Bangunan Gedung dan Non Gedung SNI 031726-2012.

[4] Badan Standarisasi Nasional,Tata Cara Perencanaan Ketahanan Gempa Untuk Struktur 
Bangunan Gedung dan Non Gedung SNI 031726-2002.

[5] Badan Standarisasi Nasional,Tata Cara Perencanaan Struktur Baja Untuk Bangunan Gedung SNI 03-1729-2002.

[6] Badan Standarisasi Nasional, Tata Cara Perhitungan Struktur Beton Bertulang Untuk Bangunan Gedung SNI 03-2847-2002.

[7] Budiono B. dkk, 2011. Studi Komparasi Desain Bangunan Tahan Gempa:Dengan Menggunakan SNI 03-1726-2002 dan RSNI 03-1726-2010, Intitut Teknologi Bandung : Bandung.

[8] Departemen Pekerjaan Umum, Peraturan Pembebanan Indonesia Untuk Gedung (PPIUG) 1983. Yayasan Badan Penerbit PU.

[9] Gunawan R., 2012. Tabel Profil Konstruksi Baja. Kanisius : Yogyakarta.

[10] Nasution A., 2009. Analisis dan Desain Struktur Beton Bertulang, Intitut Teknologi Bandung : Bandung.
[11] Nurjaman dkk,. 2007. Sistem Pracetak Beton Sebagai Sistem Konstruksi Hijau : Studi Kasus Perbandingan Energi Konstruksi Dan Dampak Lingkungan Di Pembangunan Rumah Susun Di Batam. Seminar dan Pameran HAKI 2007 : Konstruksi Tahan Gempa Di Indonesia.

[12] Satyarno dkk, 2012. Belajar SAP 2000 Analisis Gempa Seri 1. Zamil Publishing : Yogyakarta.

[13] Satyarno dkk, 2012. Belajar SAP 2000 Analisis Gempa Seri 2. Zamil Publishing : Yogyakarta.

[14] Sulistyana. 2011. Dalam Tesis "Penelitian Panel Beton Seluler dengan Rib Sebagai Pengaku" Magister Teknik Sipil Universitas Diponegoro : Semarang.

[15] Vis W. C. dan Kusuma G, 1993. Grafik dan Perhitungan Tabel Beton Bertulang, Erlangga : Jakarta.

[16] Wulfram, 2006. Eksplorasi Teknologi Dalam Proyek Konstruksi Beton Pracetak dan Bekisting, Andi Offset : Yogyakarta. 